\title{
The Na/K-ATPase Signaling: From Specific Ligands to General Reactive Oxygen Species
}

\author{
Rebecca D. Pratt, Cameron R. Brickman, Cameron L. Cottrill, Joseph I. Shapiro and Jiang Liu *(i) \\ Departments of Biomedical Sciences and Medicine Joan C. Edwards School of Medicine, Marshall University, \\ Huntington, WV 25755, USA; martin570@live.marshall.edu (R.D.P.); brickman@live.marshall.edu (C.R.B.); \\ cottrill41@live.marshall.edu (C.L.C.); shapiroj@marshall.edu (J.I.S.) \\ * Correspondence: liuj@marshall.edu; Tel.: +1-304-696-7359
}

Received: 2 July 2018; Accepted: 28 August 2018; Published: 1 September 2018

\begin{abstract}
The signaling function of the Na/K-ATPase has been established for 20 years and is widely accepted in the field, with many excellent reports and reviews not cited here. Even though there is debate about the underlying mechanism, the signaling function is unquestioned. This short review looks back at the evolution of $\mathrm{Na} / \mathrm{K}$-ATPase signaling, from stimulation by cardiotonic steroids (also known as digitalis-like substances) as specific ligands to stimulation by reactive oxygen species (ROS) in general. The interplay of cardiotonic steroids and ROS in Na/K-ATPase signaling forms a positive-feedback oxidant amplification loop that has been implicated in some pathophysiological conditions.
\end{abstract}

Keywords: Na/K-ATPase; ROS; sodium; potassium; signaling; Src. endocytosis

\section{Introduction}

Since J.C. Skou's discovery in 1957 [1], the energy-transducing Na/K-ATPase has been extensively studied for its ion-pumping function and, later on, its signaling function. The latter was first demonstrated about two decades ago and evolved into a much bigger signaling network (and has kept evolving) that one could not imagine before.

All starts with the possible role of $\mathrm{Na} / \mathrm{K}$-ATPase in cardiac hypertrophy. In a classic view, partial inhibition of $\mathrm{Na} / \mathrm{K}-\mathrm{ATPase}$ ion-exchange activity raises intracellular sodium concentration $\left(\left[\mathrm{Na}^{+}\right]_{\mathrm{i}}\right)$, which in turn increases intracellular calcium concentration $\left(\left[\mathrm{Ca}^{2+}\right]_{\mathrm{i}}\right)$ by coupling with $\mathrm{Na}^{+} / \mathrm{Ca}^{2+}$ exchanger (NCX) to execute the inotropic effect. This is the basis of the treatment of heart failure with digitalis-like drugs. Furthermore, partial inhibition of $\mathrm{Na} / \mathrm{K}$-ATPase not only causes intracellular ionic changes but also stimulates transcriptional upregulation of several marker genes including $\mathrm{Na} / \mathrm{K}$-ATPase itself. However, further studies were unable to directly link ouabain-mediated gene regulation effects to changes in intracellular $\left[\mathrm{Na}^{+}\right]_{\mathrm{i}}$ or $\left[\mathrm{K}^{+}\right]_{\mathrm{i}}$ caused by $\mathrm{Na} / \mathrm{K}$-ATPase inhibition. In cultured cardiac myocytes, treatment with nontoxic concentrations of ouabain not only partially inhibited $\mathrm{Na} / \mathrm{K}$-ATPase activity and increased cardiac contractility but also stimulated cell growth and protein synthesis through induction of early response proto-oncogenes and activation of transcription factors [2-8]. These discrepancies started the search for mechanism(s) other than ionic changes.

\section{Na/K-ATPase Signaling and Intracellular Ionic Concentration}

As mentioned above, changes in $\left[\mathrm{Na}^{+}\right]_{i},\left[\mathrm{~K}^{+}\right]_{\mathrm{i}}$, and $\left[\mathrm{Ca}^{2+}\right]_{\mathrm{i}}$ were largely attributed to changes in $\mathrm{Na} / \mathrm{K}$-ATPase activity that can be regulated by specific-ligand cardiotonic steroids. Interestingly, $\mathrm{Na} / \mathrm{K}$-ATPase activity can also be regulated by changes in cellular redox status, induced by either cardiotonic steroids or other factors. In cardiac myocytes, inhibition of $\mathrm{Na} / \mathrm{K}$-ATPase ion-exchange function leads to a decrease of $\left[\mathrm{K}^{+}\right]_{\mathrm{i}}$ and an increase of $\left[\mathrm{Na}^{+}\right]_{\mathrm{i}}$. By coupling to NCX, this increase in 
$\left[\mathrm{Na}^{+}\right]_{\mathrm{i}}$ elevates intracellular $\left[\mathrm{Ca}^{2+}\right]_{\mathrm{i}}$, which is the leading force of the positive inotropic action induced by digitalis drugs for treatment of heart failure $[9,10]$. To address the role of these ionic changes, ouabain-induced reactive oxygen species (ROS) generation (an essential second messenger) and an increase in $\left[\mathrm{Ca}^{2+}\right]_{i}$ (a shared secondary messenger) were manipulated to investigate the possible interplay. Ouabain-induced ROS generation was compared in cardiac myocytes cultured in $\mathrm{Ca}^{2+}$-free medium (with $0.1 \mathrm{mM}$ egtazic acid (EGTA)) and $\mathrm{Ca}^{2+}$-containing medium, respectively. In neonatal cardiac myocytes cultured in $\mathrm{Ca}^{2+}$-free medium, in which ouabain did not change $\left[\mathrm{Ca}^{2+}\right]_{i}$, ouabain was still able to stimulate ROS generation as shown in myocytes cultured in $\mathrm{Ca}^{2+}$-containing medium but was unable to stimulate an increase of $\left[\mathrm{Ca}^{2+}\right]_{\mathrm{i}}$ and contractility in neonatal cardiac myocytes [11]. Furthermore, in neonatal cardiac myocytes cultured in $\mathrm{Ca}^{2+}$-free medium with high $\mathrm{Na}^{+}(150 \mathrm{mM})$, monensin, a $\mathrm{Na}^{+}$-specific ionophore capable of equilibrating $\mathrm{Na}^{+}$concentration across cell membrane, failed to increase ROS generation. Interestingly, inhibition of c-Src or Ras as well as antioxidants can block ouabain-stimulated ROS generation but not ouabain-induced increases in $\left[\mathrm{Ca}^{2+}\right]_{i}[6,12,13]$. These observations suggest that increases in $\left[\mathrm{Ca}^{2+}\right]_{i}$ are necessary in ouabain-induced increases in cardiomyocytes contractility and gene regulatory effects but is not necessary in ouabain-stimulated ROS generation. Moreover, ouabain-stimulated Na/K-ATPase signaling also increases the generation of ROS, which functions as a second messenger. Pretreatment with antioxidants, such as $N$-acetylcysteine (NAC) or vitamin E, neutralized the increases of ROS and therefore prevented ouabain-stimulated activation of NF-KB and protein synthesis $[6,11]$. Ouabain-induced increases in ROS production involves the opening of mitochondrial ATP-sensitive $\mathrm{K}^{+}$channels (mitoK $\mathrm{ATP}_{\mathrm{AT}}$ ) [11,13].

Notably, ouabain-induced increases in $\left[\mathrm{Ca}^{2+}\right]_{i}$ are also involved in ouabain-stimulated $\mathrm{Na} / \mathrm{K}$-ATPase signaling. In renal epithelial cells, low doses of ouabain, which only partially inhibit $\mathrm{Na} / \mathrm{K}$-ATPase activity, functioned as an inducer/trigger of regular, low-frequency $\left[\mathrm{Ca}^{2+}\right]_{\mathrm{i}}$ oscillations, which are involved in the Na/K-ATPase/inositol 1,4,5-trisphosphate receptors $\left(\mathrm{IP}_{3} \mathrm{Rs}\right)$ signaling microdomain that leads to NF- $\mathrm{kB}$ activation $[14,15]$. This phenomenon does not depend on partial inhibition of $\mathrm{Na} / \mathrm{K}-\mathrm{ATP}$ ase using low extracellular $\mathrm{K}^{+}$and depolarization of cells but is achieved by ouabain-stimulated activation of tyrosine kinase c-Src and phospholipase C- $\gamma$ (PLC- $\gamma$ ), which transmit the signal to IP3Rs [16,17]. Depletion of intracellular endoplasmic reticulum (ER) $\mathrm{Ca}^{2+}$ by sarco/endoplasmic reticulum $\mathrm{Ca}^{2+}$ ATPase (SERCA) inhibitor, as well as blockage of store-operated calcium-mediated cytosolic $\mathrm{Ca}^{2+}$ influx and inhibition of IP3Rs-induced $\mathrm{Ca}^{2+}$, release abolished ouabain-induced $\mathrm{Ca}^{2+}$ oscillations [15]. Truncation of 32 amino acids from the $\alpha 1 \mathrm{NH}_{2}$ terminus results in a functional enzyme but abolishes ouabain-induced $\mathrm{Ca}^{2+}$ oscillations, indicating that the cytoplasmic $\alpha 1 \mathrm{NH}_{2}$ terminus plays a central role in ouabain-induced $\mathrm{Ca}^{2+}$ oscillations [15]. The data from this study also indicates that increased $\left[\mathrm{Na}^{+}\right]_{\mathrm{i}}$ is not the main cause of ouabain-induced $\mathrm{Ca}^{2+}$ oscillations, but rather the release of the $\alpha 1 \mathrm{NH}_{2}$ terminus during the $\mathrm{Na} / \mathrm{K}$-ATPase E1 to E2 conformational change (ouabain binding favors $\mathrm{E} 2$ conformation) serves as a mean of $\alpha 1 /$ IP3Rs complex formation. It was further confirmed that the $\alpha 1 \mathrm{NH}_{2}$ terminus binds directly, through motif $\mathrm{LKK}$, with the IP3R $\mathrm{NH}_{2}$ terminus [18]. On the other hand, ouabain stimulated the formation of a functional $\mathrm{Ca}^{2+}$-signaling complex, including the Na/K-ATPase $\alpha 1 / \mathrm{c}-\mathrm{Src} / \mathrm{PLC}-\gamma / \mathrm{IP}_{3} \mathrm{R}$ in LLC-PK 1 cells, and knockdown of the $\mathrm{Na} / \mathrm{K}$-ATPase $\alpha 1$ redistributed IP3R [17]. Overexpression of the $\alpha 1 \mathrm{NH}_{2}$ terminus (amino acids 1-160) not only disrupted the interaction of the $\mathrm{Na} / \mathrm{K}$-ATPase $\alpha 1$ and IP3R, but it also functioned as a negative regulator of ATP-induced ER $\mathrm{Ca}^{2+}$ release [17]. The p42/44 MAPK-mediated activation of $\mathrm{Ca}^{2+}$ channels partially contributes to ouabain-induced regulation of $\left[\mathrm{Ca}^{2+}\right]_{\mathrm{i}}[19,20]$.

Because the effects of ouabain on c-Src are independent of changes in intracellular ion concentrations [11,21-23], it seems that ouabain-induced inhibition of Na/K-ATPase enzymatic activity (ion exchange) and ouabain-induced c-Src-dependent signaling are, at least partially, two separated regulatory events under these experimental conditions. In addition to ouabain, changes in intracellular $\mathrm{Na}^{+}$or extracellular $\mathrm{K}^{+}$affect not only the enzyme conformation but also change other ion-transporter-related activities. For example, lowering of extracellular $\mathrm{K}^{+}$activates protein kinases and raises intracellular $\mathrm{Ca}^{2+}$ in cardiac myocytes [23], but it differs from the effects 
of ouabain on smooth muscle and kidney epithelial cells $[14,21]$. Large bulk changes in $\left[\mathrm{Na}^{+}\right]_{\mathrm{i}}$ or $\left[\mathrm{K}^{+}\right]_{\mathrm{i}}$ that are not induced by the ouabain-Na/K-ATPase axis also affect other intracellular signal pathways [24-26]. For example, in cultured porcine aortic endothelial cells, ouabain-mediated complete inhibition of $\mathrm{Na} / \mathrm{K}$-ATPase causes cell necrosis that is independent of ouabain-mediated ion fluxes and changes of the $\left[\mathrm{Na}^{+}\right]_{\mathrm{i}} /\left[\mathrm{K}^{+}\right]_{\mathrm{i}}$ ratio, but $\mathrm{K}^{+}$-free $\left(\left[\mathrm{K}^{+}\right]_{0}=0\right)$ medium-caused inhibition of $\mathrm{Na} / \mathrm{K}$-ATPase, which elevates $\left[\mathrm{Na}^{+}\right]_{i}$, does not induce necrosis but protects against apoptosis [27]. The antiapoptosis effect is regulated by a $\left[\mathrm{Na}^{+}\right]_{i}$-mediated, $\mathrm{Ca}^{2+}$-independent mechanism [28]. In cultured cortical neurons, ouabain-induced concentration-dependent neuron death involved apoptosis and necrosis, which is mediated by intracellular depletion of $\mathrm{K}^{+}$and accumulation of $\mathrm{Ca}^{2+}$ and $\mathrm{Na}^{+}$[29]. These observations suggest that ouabain-Na/K-ATPase-mediated signaling differs from solely ionic change $\left(\left[\mathrm{Na}^{+}\right]_{\mathrm{i}} /\left[\mathrm{K}^{+}\right]_{\mathrm{i}}\right)$-mediated signaling pathways. The possible interplay and different mechanism(s) between them are still not totally understood.

In smooth muscle cells of rat arteries, both NCX and ouabain-sensitive $\mathrm{Na}^{+} / \mathrm{K}^{+}$-ATPase $\alpha_{2^{-}}$ and $\alpha_{3}$-isoforms reside closely in plasma membrane regions adjacent to the sarcoplasmic reticulum, a subplasmalemmal space called plasmERosome [30-33]. While low doses of ouabain do not increase bulk cytosolic $\mathrm{Na}^{+}$levels, it can stimulate a local transient rise of $\left[\mathrm{Na}^{+}\right]_{\mathrm{i}}$ in the plasmERosome, which can lead to a local transient increase of $\left[\mathrm{Ca}^{2+}\right]_{i}$ via the NCX and increased muscle contractility [34-36].

In cells without expression of plasma membrane NCX, alteration of the $\left[\mathrm{Na}^{+}\right]_{\mathrm{i}} /\left[\mathrm{K}^{+}\right]_{\mathrm{i}}$ ratio, by high ouabain concentrations or palytoxin through inhibition of $\mathrm{Na}^{+} / \mathrm{K}^{+}$-ATPase, is able to activate some protein kinase signaling pathways [25-37]. This suggests that, in cells lacking NCX expression, changes in $\left[\mathrm{Na}^{+}\right]_{\mathrm{i}}$ or $\left[\mathrm{K}^{+}\right]_{\mathrm{i}}$ or both may also stimulate $\mathrm{Ca}^{2+}$-independent $\mathrm{Na}^{+} / \mathrm{K}^{+}$-ATPase signaling functions.

These observations indicate a complicated interplay amongst $\mathrm{Na} / \mathrm{K}$-ATPase ion-exchange activity, signaling, and ROS in regulation of different cellular events. The Na/K-ATPase signaling-ROS axis might play an important role in dissecting these regulations since chronic regulation of ion homeostasis could be a consequence of $\mathrm{Na} / \mathrm{K}-\mathrm{ATP}$ ase signaling and ROS regulation.

\section{Na/K-ATPase Signaling and Reactive Oxygen Species (ROS): The Positive Oxidant Amplification Loop}

The interplay amongst $\mathrm{Na}$ /K-ATPase signaling, ROS, and oxidative modifications has been a topic for decades. The effect of ROS on Na/K-ATPase activity has been well documented [6,38-46]. Different oxidative modification mechanisms and subunits of the $\mathrm{Na} / \mathrm{K}$-ATPase showed different outputs.

In rabbit ventricular myocytes, glutathionylation of cysteine residue (Cys-46) of the Na/K-ATPase $\beta 1$ subunit inhibits $\mathrm{Na} / \mathrm{K}$-ATPase activity by either stabilizing the enzyme in an E2-prone conformation, a process that could be reversibly regulated by glutaredoxin 1 and FXYD proteins (a family of seven type I small membrane proteins sharing a 35 amino acid signature domain starting with PFXYD) that are associated with $\mathrm{Na} / \mathrm{K}$-ATPase $[40,41,47]$. In rat myocardium, $S$-glutathionylation of cysteine residues (Cys-454, $-458,-459$, and-244) of the $\mathrm{Na} / \mathrm{K}$-ATPase $\alpha 1$ subunit also inhibits the Na/K-ATPase activity by blocking the ATP-binding site $\mathrm{Na} / \mathrm{K}$-ATPase $\alpha 1$ subunit when the ATP concentration below $0.5 \mathrm{mM}$. This $S$-glutathionylation of the $\alpha 1$ subunit as well as inhibition of $\mathrm{Na} / \mathrm{K}$-ATPase activity can be reversed by deglutathionylation with glutaredoxin or dithiothreitol $[42,48]$. In various chronic inflammatory conditions, circulating cardiotonic steroids are elevated that are capable of stimulating a proinflammatory response in murine and human macrophages. This process involves ouabain-stimulated activation of NF- $\mathrm{KB}$ through a signaling complex of $\mathrm{Na} / \mathrm{K}-\mathrm{ATPase}$, CD36, and TLR4, leading to increases in proinflammatory cytokines MCP-1, TNF- $\alpha$, IL-1 $\beta$, and IL-6 [49-51].

In rat neonatal myocytes, ouabain-stimulated activation of the $\mathrm{Na} / \mathrm{K}$-ATPase signaling function increases mitochondrial ROS generation that functions as an essential second messenger [6,11]. More importantly, increases in ROS can cause conformational changes in Na/K-ATPase like ouabain [39-42,44,47]. One question asked was that if ROS is able to stimulate the signaling function of $\mathrm{Na} / \mathrm{K}$-ATPase like ouabain, and if ouabain (or ROS) $\rightarrow \mathrm{Na} / \mathrm{K}$-ATPase signaling $\rightarrow$ ROS $\rightarrow$ $\mathrm{Na} / \mathrm{K}$-ATPase signaling could form a positive amplification loop that could amplify $\mathrm{Na} / \mathrm{K}$-ATPase 
and subsequent signaling events and functional changes. This is of particular interest since it was well accepted that ROS play an important role in the pathogenesis of cardiovascular diseases, chronic kidney diseases, and many others.

In primary cultures of cardiac myocytes, it was demonstrated that partial inhibition of $\mathrm{Na} / \mathrm{K}-\mathrm{ATPase}$ by ouabain stimulated c-Src- and Ras-dependent signaling which lead to mitochondrial $\mathrm{K}_{\text {ATP }}$ channel-related ROS generation, and that ouabain-induced cardiac hypertrophic growth involved ROS-dependent signaling pathways [6]. In Langendorff-perfused rat hearts, pretreatment with ouabain demonstrated a cardioprotective effects against ischemia-reperfusion injury by an improved recovery of contractile function and a reduction of infarct size. This ouabain effect is due to activation of the $\mathrm{Na} / \mathrm{K}-\mathrm{ATPa} e$ signaling function that involves $\mathrm{Src}$, the mitochondrial $\mathrm{K}_{\mathrm{ATP}}$ channel, and ROS [52]. Exogenous ROS (for example, induced by glucose oxidase) acting as ouabain also caused ROS-dependent cardiac hypertrophic growth. Inhibition of c-Src and ERK1/2 abrogated the effects of ROS-induced protein synthesis that was not affected by chelating intracellular $\mathrm{Ca}^{2+}$ by BAPTA-AM [53]. Moreover, ouabain-induced increase in $\left[\mathrm{Ca}^{2+}\right]_{i}$ was ROS-independent and involved mainly the inhibition of the $\mathrm{Na} / \mathrm{K}$-ATPase ion transport function [11]. These observations indicated that ROS act like ouabain, and the Na/K-ATPase could be a target for ROS-initiated signaling.

In porcine LLC-PK1 cells (an immobilized renal proximal tubule cell line), exogenous $\mathrm{H} 2 \mathrm{O} 2$ activated $\mathrm{Na} / \mathrm{K}-\mathrm{ATP}$ ase signaling pathways including phosphorylation of c-Src and ERK1/2 [54]. By using LLC-PK1 cells, it was further demonstrated that a low concentration of ouabain also stimulated the $\mathrm{Na} / \mathrm{K}-\mathrm{ATPase}$ signaling function, which led to increased ROS generation and protein carbonylation modification of $\mathrm{Na} / \mathrm{K}-\mathrm{ATPase}$ (direct carbonylation of two amino acid residues, Pro222 and Thr224, in the actuator domain of the $\alpha 1$ subunit) [45]. Pretreatment with antioxidant $\mathrm{N}$-acetyl-L-cysteine (NAC) or disruption of the Na/K-ATPase/c-Src signaling complex attenuated ouabain- and glucose-oxidase-stimulated Na/K-ATPase/c-Src signaling, protein carbonylation, redistribution of $\mathrm{Na} / \mathrm{K}-\mathrm{ATP}$ ase, and inhibition of active transepithelial ${ }^{22} \mathrm{Na}^{+}$transport. This indicated that ROS are critical in initiating ouabain-stimulated Na/K-ATPase/c-Src signaling, and carbonylation modification of the $\alpha 1$ subunit is involved in a feed-forward mechanism of regulation of ouabain-mediated $\mathrm{Na} / \mathrm{K}-\mathrm{ATP}$ ase signal function and subsequent $\mathrm{Na}^{+}$transport. Interestingly, there is an undefined "decarbonylation" mechanism of ouabain-stimulated protein carbonylation after removal of ouabain, which could be another new regulatory mechanism of $\mathrm{Na} / \mathrm{K}$-ATPase signaling because it was believed that protein carbonylation modification could not be reversed. Furthermore, stable overexpression of rat $\alpha 1$ mutant Pro224/Ala (Pro224 of rat $\alpha 1$ is the same as the Pro222 of pig $\alpha 1$ ) prevented the ouabain-stimulated signal function of $\mathrm{Na} / \mathrm{K}$-ATPase, protein carbonylation, $\mathrm{Na} / \mathrm{K}-\mathrm{ATP}$ ase endocytosis, and active transepithelial ${ }^{22} \mathrm{Na}^{+}$transport [46]. Taken together, we proposed that, in LLC-PK1 cells, there is a positive-feedback amplification loop of Na/K-ATPase signaling and ROS generation, in which carbonylation of the Pro222 of the $\alpha 1$ subunit plays a critical role. In this working model, both $\mathrm{Na} / \mathrm{K}$-ATPase specific-ligand cardiotonic steroids (including ouabain) and ROS increases (induced by other stimuli, including exogenous-added glucose oxidase) could activate Na/K-ATPase signaling. The Na/K-ATPase/c-Src complex functions as a "receptor" of ROS signaling. This $\mathrm{Na} / \mathrm{K}-\mathrm{ATP}$ ase signaling-ROS axis may explain the role of $\mathrm{Na} / \mathrm{K}$-ATPase signaling in the development of different pathophysiological conditions. However, it is not clear (1) if a decarbonylation process could regulate the carbonylation modification, and (2) to which point the oxidant amplification loop will be forced to stop.

\section{Na/K-ATPase Signaling and pNaKtide: A Specific Antagonist of c-Src Kinase that Breaks the Oxidant Amplification Loop}

One question regarding the abovementioned "Na/K-ATPase signaling-mediated oxidant amplification loop" is, could this amplification loop be controlled and targeted for possible therapeutic implication(s)? In the Na/K-ATPase/c-Src signaling complex model, it was demonstrated that the $\alpha 1$ ND1 domain binds to the c-Src tyrosine kinase domain and the $\alpha 1$ CD2 domain binds to the c-Src SH2 
domain in the "resting" state [55]. Upon ouabain stimulation, c-Src is activated (phosphorylation of Tyr418) due to the disruption of the binding between the $\alpha 1$ ND1 domain and the c-Src tyrosine kinase domain. Based on this working model, mapping of these domains led to the identification of a peptide named NaKtide (derived from the Ser415-Gln434 of the pig $\alpha 1$ ND1 domain). In order to further explore this relationship, a cell-permeable version of NaKtide, named pNaKtide, was created. A 13-amino-acid TAT leader sequence makes pNaKtide positive and therefore cell permeable. pNaKtide targets the $\alpha 1 /$ Src receptor complex close to the plasma membrane inside the cell $[41,56]$. Both NaKtide and pNaKtide act as specific antagonists of c-Src phosphorylation (Figure 1), further demonstrating that the binding of the $\alpha 1$ and c-Src and the conformational change are critical in the activation of $\mathrm{Na} / \mathrm{K}-\mathrm{ATPase}$ signaling.
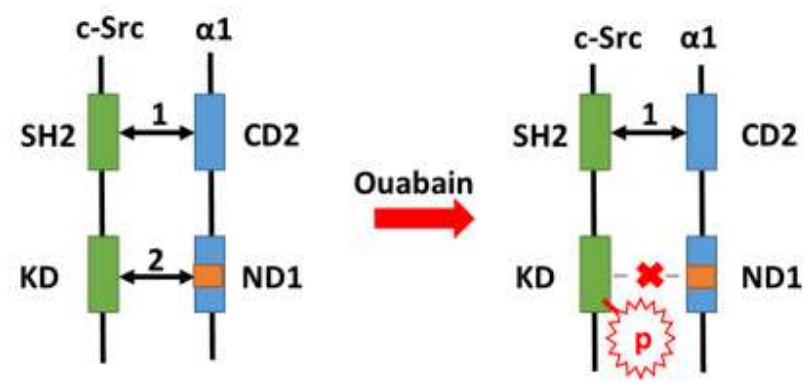

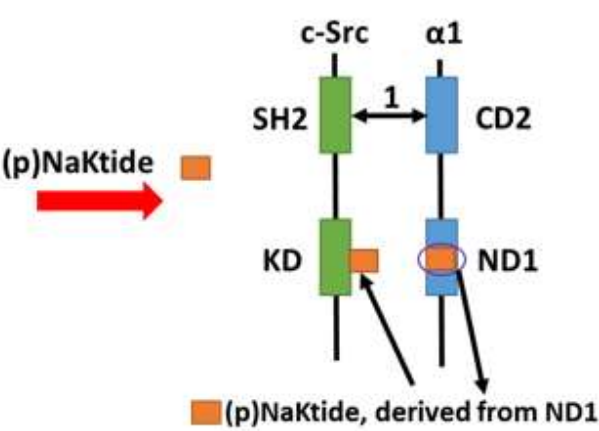

\section{Control State (Inactive) Ouabain Stimulated (Active) \\ (p)NaKtide Inhibited (inactive)}

Figure 1. A schematic illustration of action of pNaKtide: Under control state, c-Src SH2 domain binds to $\alpha 1$ CD2 segment (indicated by arrow 1) and c-Src KD binds to $\alpha 1$ ND1 (indicated by arrow 2), which keeps c-Src inactive. Upon ouabain binding to the $\alpha 1$ subunit, the $\alpha 1$ subunit favors E- $2 \mathrm{P}$ conformational status and c-Src KD released from $\alpha 1$ subunit that leads to phosphorylation of Tyr418 in c-Src KD. NaKtide and pNaKtide are derived from 20 aa (Ser415-Gln434) in $\alpha 1$ ND1, which can bind to the c-Src KD for the competitive binding of $\alpha 1$ ND1 and KD, thus preventing phosphorylation of Tyr418 in c-Src KD. In the illustration, ouabain is used as a representative of cardiotonic steroids. $\mathrm{SH} 2$, c-Src SH2 domain; KD, c-Src kinase domain; CD2, $\alpha 1$ subunit CD2 segment; ND1, $\alpha 1$ subunit ND1 segment.

Oxidative stress plays an important role in many pathophysiological conditions. The role of pNaKtide in $\mathrm{Na} / \mathrm{K}$-ATPase signaling-mediated oxidant amplification loop has been investigated in different cell types and animal models. For example, systemic administration of pNaKtide significantly and effectively attenuates (1) 5/6th partial nephrectomy (PNx)-induced uremic cardiomyopathy phenotypes in C57BL/ 6 mice [57]; (2) high-fat-diet-induced adipogenesis, a model of obesity and metabolic syndrome [58]; (3) Western-diet-induced (containing high fat and high fructose) obesity, hepatic steatosis, and fibrosis in C57BL/ 6 mice, as well as steatohepatitis and aortic atherosclerosis in ApoE knockout mice [59]; (4) a Western-diet-accelerated aging process involving nuclear oxidative stress in C57BL/6 mice [60]; as well as (5) unilateral ureteral obstruction (UUO)-mediated interstitial fibrosis in C57BL/6J mice [61]. In these animal models, administration of pNaKtide specifically breaks $\mathrm{Na} / \mathrm{K}$-ATPase signaling-mediated oxidant amplification loop, demonstrated by pNaKtide-induced attenuation of c-Src activation, protein carbonylation, and other regulations. More molecular mechanistic studies are necessary for possible therapeutic usage.

\section{Na/K-ATPase Signaling-Mediated Transporter Endocytosis and Renal Sodium Handling}

Over the last decade, the role of $\mathrm{Na} / \mathrm{K}$-ATPase signaling in renal proximal tubular sodium handling and the role of oxidative modification of the $\mathrm{Na} / \mathrm{K}$-ATPase $\alpha 1$ subunit in $\mathrm{Na} / \mathrm{K}$-ATPase 
signaling were explored both in vitro and in vivo. The findings may explain some mechanism(s) related to the $\mathrm{Na} / \mathrm{K}$-ATPase signaling-ROS amplification loop and subsequent regulation of salt-sensitivity.

It is well documented that the renal proximal tubule mediates over $60 \%$ of the filtered $\mathrm{Na}^{+}$ reabsorption, mainly through apical $\mathrm{Na}^{+}$entry via NHE3 and basolateral $\mathrm{Na}^{+}$extrusion through the $\mathrm{Na} / \mathrm{K}$-ATPase. Coordinated and coupled regulation of NHE3 and the Na/K-ATPase is critical in maintaining intracellular $\mathrm{Na}^{+}$homeostasis and extracellular fluid volume [62-64].

In LLC-PK1 cells such as dopamine [65-68], low concentrations of ouabain stimulate endocytosis of the $\alpha 1 / \beta 1$ subunits, NHE3 $\left(\mathrm{Na}^{+} / \mathrm{H}^{+}\right.$exchanger, isoform 3$)$, and c-Src into early and/or late endosomes, leading to net decreases in abundance of Na/K-ATPase and NHE3 in cell surface, and thus decreases in transcellular ${ }^{22} \mathrm{Na}^{+}$transport [62,69-75]. This phenomenon is mainly through a clathrin-dependent endocytic pathway and requires caveolin-1 and activation of c-Src and PI3K. Furthermore, ouabain-induced endocytosis of Na/K-ATPase and NHE3 decreases in transcellular ${ }^{22} \mathrm{Na}^{+}$reabsorption and is dependent on the ouabain-stimulated signaling function of $\mathrm{Na} / \mathrm{K}-\mathrm{ATPase}$ without significantly affecting $\left[\mathrm{Na}^{+}\right]_{\mathrm{i}}[70,76,77]$. Inhibition of c-Src and PI3K activity prevented ouabain-induced endocytosis of Na/K-ATPase and NHE3. Pretreatment of LLC-PK1 cells with membrane-permeable $\mathrm{Ca}^{2+}$ chelator BAPTA-AM attenuated ouabain-induced regulation of NHE3 [77], suggesting ouabain-induced $\mathrm{Ca}^{2+}$ signaling might be involved in regulation [14]. In male Sprague-Dawley rats fed a high-salt $(4.0 \% \mathrm{NaCl})$ or normal-salt $(0.4 \% \mathrm{NaCl})$ diet for 1 week, a high-salt diet redistributes the $\mathrm{Na} / \mathrm{K}$-ATPase $\alpha 1$ subunit from plasma membrane fraction to early/late endosomes, accompanied by a reduction of proximal tubular $\mathrm{Na} / \mathrm{K}$-ATPase ion-exchange activity and enzymatic activity but an increase in urinary excretion of marinobufagenin (MBG) and sodium. These effects were attenuated by administration of anti-MBG antibody prior to salt load [74]. Moreover, this observation was further confirmed in vivo. By using Dahl salt-sensitive and salt-resistant rats (Jr strains) as models, in vivo studies demonstrated that impairment of renal proximal tubular $\mathrm{Na} / \mathrm{K}-\mathrm{ATPase}$ signaling causes experimental Dahl salt sensitivity [78]. In Dahl salt-resistant but not salt-sensitive rats, a high-salt $(2 \% \mathrm{NaCl}, 1$ week) diet activated proximal tubular $\mathrm{Na} / \mathrm{K}$-ATPase signaling and stimulated coordinated redistribution of the Na/K-ATPase and NHE3, leading to increases in total and fractional urinary sodium excretion as well as normal blood pressure. However, the mechanism(s) underlying the difference of $\mathrm{Na} / \mathrm{K}$-ATPase signaling function between Dahl salt-sensitive and salt-resistant rats, as well as the translation of $\mathrm{Na} / \mathrm{K}$-ATPase signaling to NHE3 regulation, are still unclear.

It is well established that both oxidative stress and high blood pressure are causes and consequences of each other. Based on the findings of the amplification loop of $\mathrm{Na} / \mathrm{K}$-ATPase signaling and ROS generation, we tested whether oxidative stress could activate the signaling function of $\mathrm{Na} / \mathrm{K}$-ATPase and induce the abovementioned endocytosis process and regulation of renal sodium handling. In our working model, increases in ROS generation, either by ouabain or by other stimuli such as glucose oxidase, are critical in activation of Na/K-ATPase signaling, which mediates transporter trafficking, transcellular $\mathrm{Na}^{+}$transport, and urinary sodium excretion [45,46]. On the one hand, pretreatment with antioxidant NAC abrogates ouabain-stimulated $\mathrm{Na} / \mathrm{K}$-ATPase signaling and transcellular $\mathrm{Na}^{+}$transport, suggesting that a certain level of basal ROS is required for initiation of Na/K-ATPase signaling. On the other hand, without the presence of ouabain, increases in ROS by extracellularly added glucose oxidase are able to activate $\mathrm{Na} / \mathrm{K}$-ATPase signaling, indicating that activation of $\mathrm{Na} / \mathrm{K}-\mathrm{ATP}$ ase signaling does require its specific ligands and that general stimuli, such as oxidative modification alone, are able to activate $\mathrm{Na} / \mathrm{K}$-ATPase signaling [79].

However, the effect(s) and consequence(s) of ouabain- and ROS-induced endocytosis of $\mathrm{Na} / \mathrm{K}$-ATPase/c-Src/EGFR $[70,71]$ are not clear. It has been shown that endocytosis of signaling molecules could be a way to terminate or propagate signaling and could further regulate endocytosis itself [80-87]. In this regard, it is possible that ouabain- and ROS-induced endocytosis could be an effective way to terminate the $\mathrm{Na} / \mathrm{K}$-ATPase signaling-mediated oxidant amplification loop by 
degradation of carbonylated $\mathrm{Na} / \mathrm{K}$-ATPase to maintain certain basal level of ROS and carbonylated protein [88].

\section{Perspectives: The Working Models of Na/K-ATPase Signaling}

There are different proposed working models which explain the mechanisms underlying the activation of the Na/K-ATPase signaling function, including: (1) the direct interaction of the $\mathrm{Na} / \mathrm{K}$-ATPase $\alpha 1$ subunit with c-Src kinase which forms a functional $\mathrm{Na} / \mathrm{K}-\mathrm{ATPase} / \mathrm{c}-\mathrm{Src}$ signaling receptor complex, a model has been demonstrated both in vitro and in vivo [55,89-91]; (2) c-Src is activated primarily by an ATP-sparing effect (observed in a cell-free system) [92,93]; and (3) c-Src is activated by transient interaction with a $\mathrm{Na} / \mathrm{K}$-ATPase $\alpha 1$ /caveolin- 1 complex (also observed in a cell-free system) [94] (Figure 2). In these models, there is no doubt that c-Src activation is a proximal step in $\mathrm{Na} / \mathrm{K}$-ATPase signaling. It is not a surprise that different working models are proposed based on different experimental systems, and an ideal working model is developed based on new developments and new technologies. As mentioned above, ouabain (and other cardiotonic steroids), ROS, reactive nitrogen species (RNS), changes of ionic concentrations (bulky or local), and other stimuli can activate different signaling pathways to excute different functional regulations. Moreover, these different signaling pathways and functional regulations are also cell-dependent. A common charateristic in these working models is that they are, at least partially, dependent on the conformation change. Specifically, the E2-P conformational state of the Na/K-ATPase is favored and stabilized by $\mathrm{Na} / \mathrm{K}-\mathrm{ATP} a \mathrm{se}$ inhibitors (ouabain, vanadate, oligomycin), energy status (ATP/ADP ratio), and change in $\left[\mathrm{Na}^{+}\right]$and $\left[\mathrm{K}^{+}\right]$. While the E2-P conformational state of the $\mathrm{Na} / \mathrm{K}$-ATPase is favored, a "slower" dynamic E-2P $\leftrightarrow$ E1-P conformational change (in the presence of inhibitors and/or energy status) might be an effective way to maintain and control the signaling strength and function. Nevertheless, these hypotheses need to be experimentally demonstrated.
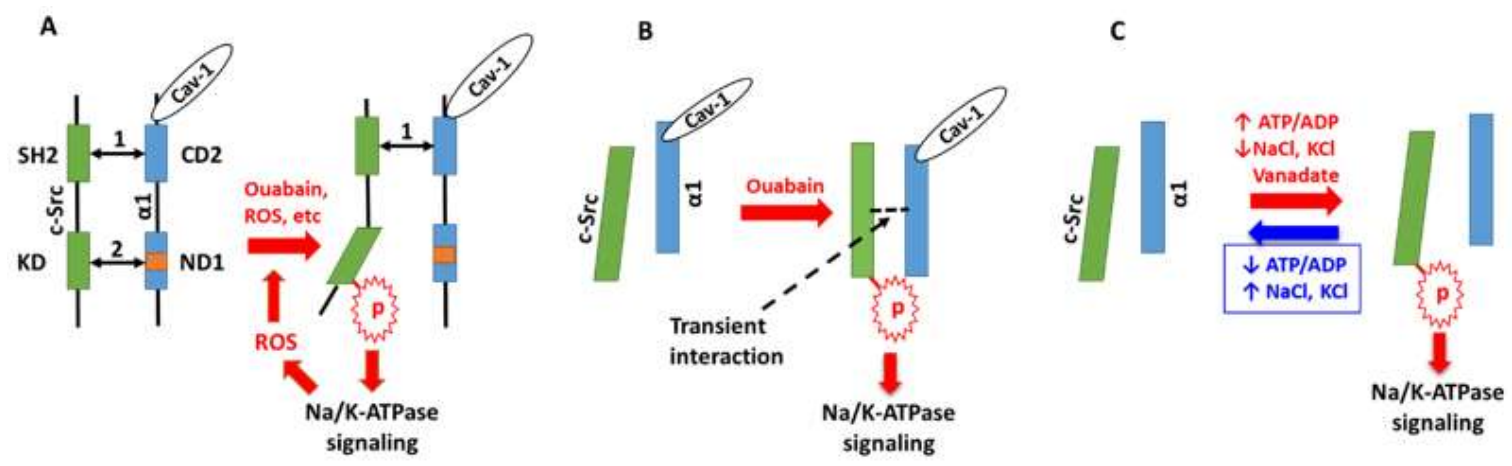

Figure 2. Schematic illustration of different working models. In the illustration, ouabain is used as a representative of cardiotonic steroids. (A) The model of Na/K-ATPase/c-Src (binding) receptor complex. Binding between c-Src SH2 domain and $\alpha 1 \mathrm{CD} 2$ segment as well as c-Src KD domain and $\alpha 1$ ND1 segment are indicated by arrow 1 and 2, respectively. (B) the model of c-Src activation by transiently binding to Na/K-ATPase/Cav-1 complex; (C) the model of c-Src activation regulated by the ATP/ADP ratio, ATPase inhibitor vanadate, and low concentrations of $\mathrm{Na}^{+}$and $\mathrm{K}^{+}$. In this model, there is no binding between $\mathrm{Na} / \mathrm{K}-\mathrm{ATPase}$ and c-Src. The role of Cav-1 was not tested. Please refer to the references for details. Cav-1, caveolin-1; ROS, reactive oxygen species.

Funding: This work was supported by NIH R15 1R15DK106666 (to J.L.) and NIH RO1 HL071556 (to J.I.S.).

Conflicts of Interest: The authors declare no conflicts of interest. 


\section{References}

1. Skou, J.C. The influence of some cations on an adenosine triphosphatase from peripheral nerves. Biochim. Biophys. Acta 1957, 23, 394-401. [CrossRef]

2. Peng, M.; Huang, L.; Xie, Z.; Huang, W.H.; Askari, A. Partial inhibition of $\mathrm{Na}^{+} / \mathrm{K}^{+}$-ATPase by ouabain induces the $\mathrm{Ca}^{2+}$-dependent expressions of early-response genes in cardiac myocytes. J. Biol. Chem. 1996, 271, 10372-10378. [CrossRef] [PubMed]

3. Huang, L.; Li, H.; Xie, Z. Ouabain-induced hypertrophy in cultured cardiac myocytes is accompanied by changes in expression of several late response genes. J. Mol. Cell. Cardiol. 1997, 29, 429-437. [CrossRef] [PubMed]

4. Huang, L.; Kometiani, P.; Xie, Z. Differential regulation of Na/K-ATPase alpha-subunit isoform gene expressions in cardiac myocytes by ouabain and other hypertrophic stimuli. J. Mol. Cell. Cardiol. 1997, 29, 3157-3167. [CrossRef] [PubMed]

5. Kometiani, P.; Li, J.; Gnudi, L.; Kahn, B.B.; Askari, A.; Xie, Z. Multiple signal transduction pathways link $\mathrm{Na}^{+} / \mathrm{K}^{+}$-ATPase to growth-related genes in cardiac myocytes. The roles of Ras and mitogen-activated protein kinases. J. Biol. Chem. 1998, 273, 15249-15256. [CrossRef] [PubMed]

6. Xie, Z.; Kometiani, P.; Liu, J.; Li, J.; Shapiro, J.I.; Askari, A. Intracellular reactive oxygen species mediate the linkage of $\mathrm{Na}^{+} / \mathrm{K}^{+}$-ATPase to hypertrophy and its marker genes in cardiac myocytes. J. Biol. Chem. 1999, 274, 19323-19328. [CrossRef] [PubMed]

7. Sugden, P.H. Signaling in myocardial hypertrophy: Life after calcineurin? Circ. Res. 1999, 84, 633-646. [CrossRef] [PubMed]

8. Xie, Z.; Askari, A. Na/K-ATPase as a signal transducer. Eur. J. Biochem. 2002, 269, 2434-2439. [CrossRef] [PubMed]

9. Barry, W.H.; Hasin, Y.; Smith, T.W. Sodium pump inhibition, enhanced calcium influx via sodium-calcium exchange, and positive inotropic response in cultured heart cells. Circ. Res. 1985, 56, 231-241. [CrossRef] [PubMed]

10. Reuter, H.; Reuter, H.; Pott, C.; Goldhaber, J.I.; Henderson, S.A.; Philipson, K.D.; Schwinger, R.H. Na ${ }^{+}-\mathrm{Ca}^{2+}$ exchange in the regulation of cardiac excitation-contraction coupling. Cardiovasc. Res. 2005, 67, 198-207. [CrossRef] [PubMed]

11. Liu, J.; Tian, J.; Haas, M.; Shapiro, J.I.; Askari, A.; Xie, Z. Ouabain interaction with cardiac $\mathrm{Na}^{+} / \mathrm{K}^{+}$-ATPase initiates signal cascades independent of changes in intracellular $\mathrm{Na}^{+}$and $\mathrm{Ca}^{2+}$ concentrations. J. Biol. Chem. 2000, 275, 27838-27844. [PubMed]

12. Tian, J.; Gong, X.; Xie, Z. Signal-transducing function of $\mathrm{Na}^{+}-\mathrm{K}^{+}$-ATPase is essential for ouabain's effect on $\left[\mathrm{Ca}^{2+}\right]_{\mathrm{i}}$ in rat cardiac myocytes. Am. J. Physiol. Heart Circ. Physiol. 2001, 281, H1899-H1907. [CrossRef] [PubMed]

13. Tian, J.; Tian, J.; Liu, J.; Garlid, K.D.; Shapiro, J.I.; Xie, Z. Involvement of mitogen-activated protein kinases and reactive oxygen species in the inotropic action of ouabain on cardiac myocytes. A potential role for mitochondrial K $\mathrm{ATP}$ channels. Mol. Cell. Biochem. 2003, 242, 181-187. [CrossRef] [PubMed]

14. Aizman, O.; Uhlén, P.; Lal, M.; Brismar, H.; Aperia, A. Ouabain, a steroid hormone that signals with slow calcium oscillations. Proc. Natl. Acad. Sci. USA 2001, 98, 13420-13424. [CrossRef] [PubMed]

15. Miyakawa-Naito, A.; Uhlén, P.; Lal, M.; Aizman, O.; Mikoshiba, K.; Brismar, H.; Zelenin, S.; Aperia, A. Cell signaling microdomain with $\mathrm{Na}, \mathrm{K}-\mathrm{ATPase}$ and inositol 1,4,5-trisphosphate receptor generates calcium oscillations. J. Biol. Chem. 2003, 278, 50355-50361. [CrossRef] [PubMed]

16. Yuan, Z.; Cai, T.; Tian, J.; Ivanov, A.V.; Giovannucci, D.R.; Xie, Z. Na/K-ATPase tethers phospholipase C and IP3 receptor into a calcium-regulatory complex. Mol. Biol. Cell 2005, 16, 4034-4045. [CrossRef] [PubMed]

17. Chen, Y.; Cai, T.; Yang, C.; Turner, D.A.; Giovannucci, D.R.; Xie, Z. Regulation of inositol 1,4,5-trisphosphate receptor-mediated calcium release by the $\mathrm{Na} / \mathrm{K}$-ATPase in cultured renal epithelial cells. J. Biol. Chem. 2008, 283, 1128-1136. [CrossRef] [PubMed]

18. Zhang, S.; Malmersjo, S.; Li, J.; Ando, H.; Aizman, O.; Uhlén, P.; Mikoshiba, K.; Aperia, A. Distinct role of the N-terminal tail of the Na,K-ATPase catalytic subunit as a signal transducer. J. Biol. Chem. 2006, 281, 21954-21962. [CrossRef] [PubMed]

19. Marban, E.; Tsien, R.W. Enhancement of calcium current during digitalis inotropy in mammalian heart: Positive feed-back regulation by intracellular calcium? J. Physiol. 1982, 329, 589-614. [CrossRef] [PubMed] 
20. Fitzgerald, E.M. Regulation of voltage-dependent calcium channels in rat sensory neurones involves a Ras-mitogen-activated protein kinase pathway. J. Physiol. 2000, 527, 433-444. [CrossRef] [PubMed]

21. Aydemir-Koksoy, A.; Abramowitz, J.; Allen, J.C. Ouabain-induced signaling and vascular smooth muscle cell proliferation. J. Biol. Chem. 2001, 276, 46605-46611. [CrossRef] [PubMed]

22. Haas, M.; Wang, H.; Tian, J.; Xie, Z. Src-mediated inter-receptor cross-talk between the $\mathrm{Na}^{+} / \mathrm{K}^{+}$-ATPase and the epidermal growth factor receptor relays the signal from ouabain to mitogen-activated protein kinases. J. Biol. Chem. 2002, 277, 18694-18702. [CrossRef] [PubMed]

23. Haas, M.; Askari, A.; Xie, Z. Involvement of Src and epidermal growth factor receptor in the signal-transducing function of $\mathrm{Na}^{+} / \mathrm{K}^{+}$-ATPase. J. Biol. Chem. 2000, 275, 27832-27837. [CrossRef] [PubMed]

24. Pressley, T.A. Ionic regulation of $\mathrm{Na}^{+}, \mathrm{K}^{+}$-ATPase expression. Semin. Nephrol. 1992, 12, 67-71. [PubMed]

25. Kuroki, D.W.; Minden, A.; Sánchez, I.; Wattenberg, E.V. Regulation of a c-Jun amino-terminal kinase/stressactivated protein kinase cascade by a sodium-dependent signal transduction pathway. J. Biol. Chem. 1997, 272, 23905-23911. [CrossRef] [PubMed]

26. Li, S.; Wattenberg, E.V. Differential activation of mitogen-activated protein kinases by palytoxin and ouabain, two ligands for the $\mathrm{Na}^{+}, \mathrm{K}^{+}$-ATPase. Toxicol. Appl. Pharmacol. 1998, 151, 377-384. [CrossRef] [PubMed]

27. Orlov, S.N.; Thorin-Trescases, N.; Pchejetski, D.; Taurin, S.; Farhat, N.; Tremblay, J.; Thorin, E.; Hamet, P. $\mathrm{Na}^{+} / \mathrm{K}^{+}$pump and endothelial cell survival: $\left[\mathrm{Na}^{+}\right] \mathrm{i} /\left[\mathrm{K}^{+}\right] \mathrm{i}$-independent necrosis triggered by ouabain, and protection against apoptosis mediated by elevation of $\left[\mathrm{Na}^{+}\right]_{\mathrm{i}}$. Pflugers Arch. 2004, 448, 335-345. [CrossRef] [PubMed]

28. Taurin, S.; Dulin, N.O.; Pchejetski, D.; Grygorczyk, R.; Tremblay, J.; Hamet, P.; Orlov, S.N. c-Fos expression in ouabain-treated vascular smooth muscle cells from rat aorta: Evidence for an intracellular-sodium-mediated, calcium-independent mechanism. J. Physiol. 2002, 543, 835-847. [CrossRef] [PubMed]

29. Xiao, A.Y.; Wei, L.; Xia, S.; Rothman, S.; Yu, S.P. Ionic mechanism of ouabain-induced concurrent apoptosis and necrosis in individual cultured cortical neurons. J. Neurosci. 2002, 22, 1350-1362. [CrossRef] [PubMed]

30. Golovina, V.A.; Song, H.; James, P.F.; Lingrel, J.B.; Blaustein, M.P. $\mathrm{Na}^{+}$pump alpha 2-subunit expression modulates $\mathrm{Ca}^{2+}$ signaling. Am. J. Physiol. Cell Physiol. 2003, 284, C475-C486. [CrossRef] [PubMed]

31. Juhaszova, M.; Blaustein, M.P. $\mathrm{Na}^{+}$pump low and high ouabain affinity alpha subunit isoforms are differently distributed in cells. Proc. Natl. Acad. Sci. USA 1997, 94, 1800-1805. [CrossRef] [PubMed]

32. Juhaszova, M.; Blaustein, M.P. Distinct distribution of different $\mathrm{Na}^{+}$pump alpha subunit isoforms in plasmalemma. Ann. N. Y. Acad. Sci. 1997, 834, 524-536. [CrossRef] [PubMed]

33. Moore, E.D.; Etter, E.F.; Philipson, K.D.; Carrington, W.A.; Fogarty, K.E.; Lifshitz, L.M.; Fay, F.S. Coupling of the $\mathrm{Na}^{+} / \mathrm{Ca}^{2+}$ exchanger, $\mathrm{Na}^{+} / \mathrm{K}^{+}$pump and sarcoplasmic reticulum in smooth muscle. Nature 1993, 365, 657-660. [CrossRef] [PubMed]

34. Arnon, A.; Hamlyn, J.M.; Blaustein, M.P. Ouabain augments $\mathrm{Ca}^{2+}$ transients in arterial smooth muscle without raising cytosolic $\mathrm{Na}^{+}$. Am. J. Physiol. Heart Circ. Physiol. 2000, 279, H679-H691. [CrossRef] [PubMed]

35. Arnon, A.; Hamlyn, J.M.; Blaustein, M.P. Na entry via store-operated channels modulates $\mathrm{Ca}^{2+}$ signaling in arterial myocytes. Am. J. Physiol. Cell Physiol. 2000, 278, C163-C173. [CrossRef] [PubMed]

36. Lee, M.Y.; Song, H.; Nakai, J.; Ohkura, M.; Kotlikoff, M.I.; Kinsey, S.P.; Golovina, V.A.; Blaustein, M.P. Local subplasma membrane $\mathrm{Ca}^{2+}$ signals detected by a tethered $\mathrm{Ca}^{2+}$ sensor. Proc. Natl. Acad. Sci. USA 2006, 103, 13232-13237. [CrossRef] [PubMed]

37. Contreras, R.G.; Shoshani, L.; Flores-Maldonado, C.; Lazaro, A.; Cereijido, M. Relationship between $\mathrm{Na}(+), \mathrm{K}(+)$-ATPase and cell attachment. J. Cell Sci. 1999, 112, 4223-4232. [PubMed]

38. Huang, W.H.; Wang, Y.; Askari, A. $\left(\mathrm{Na}^{+}+\mathrm{K}^{+}\right)$-ATPase: Inactivation and degradation induced by oxygen radicals. Int. J. Biochem. 1992, 24, 621-626. [PubMed]

39. Huang, W.H.; Wang, Y.; Askari, A.; Zolotarjova, N.; Ganjeizadeh, M. Different sensitivities of the $\mathrm{Na}^{+} / \mathrm{K}^{+}$-ATPase isoforms to oxidants. Biochim. Biophys. Acta 1994, 1190, 108-114. [CrossRef]

40. Figtree, G.A.; Keyvan, K.G.; Liu, C.C.; Rasmussen, H.H. Oxidative regulation of the $\mathrm{Na}(+)-\mathrm{K}(+)$ pump in the cardiovascular system. Free Radic. Biol. Med. 2012, 53, 2263-2268. [CrossRef] [PubMed]

41. Figtree, G.A.; Liu, C.C.; Bibert, S.; Hamilton, E.J.; Garcia, A.; White, C.N.; Chia, K.K.M.; Cornelius, F.; Geering, K.; Rasmussen, H.H. Reversible oxidative modification: A key mechanism of $\mathrm{Na}^{+}-\mathrm{K}^{+}$pump regulation. Circ. Res. 2009, 105, 185-193. [CrossRef] [PubMed] 
42. Petrushanko, I.Y.; Yakushev, S.; Mitkevich, V.A.; Kamanina, Y.V.; Ziganshin, R.H.; Meng, X.; Anashkina, A.A.; Makhro, A.; Lopina, O.D.; Gassmann, M.; et al. S-glutathionylation of the Na,K-ATPase catalytic alpha subunit is a determinant of the enzyme redox sensitivity. J. Biol. Chem. 2012, 287, 32195-32205. [CrossRef] [PubMed]

43. ThÉvenod, F.; Friedmann, J.M. Cadmium-mediated oxidative stress in kidney proximal tubule cells induces degradation of $\mathrm{Na}^{+} / \mathrm{K}^{+}$-ATPase through proteasomal and endo-/lysosomal proteolytic pathways. FASEB J. 1999, 13, 1751-1761. [CrossRef] [PubMed]

44. Xie, Z.; Wang, Y.; Askari, A.; Huang, W.H.; Klaunig, J.E.; Askari, A. Studies on the specificity of the effects of oxygen metabolites on cardiac sodium pump. J. Mol. Cell. Cardiol. 1990, 22, 911-920. [CrossRef]

45. Yan, Y.; Shapiro, A.P.; Haller, S.; Katragadda, V.; Liu, L.; Tian, J.; Basrur, V.; Malhotra, D.; Xie, Z.; Abraham, N.G.; et al. The Involvement of reactive oxygen species in a feed-forward mechanism of $\mathrm{Na}$ /K-ATPase-mediated signaling transduction. J. Biol. Chem. 2013, 288, 34249-34258. [CrossRef] [PubMed]

46. Yan, Y.; Shapiro, A.P.; Mopidevi, B.R.; Chaudhry, M.A.; Maxwell, K.; Haller, S.T.; Drummond, C.A.; Kennedy, D.J.; Tian, J.; Malhotra, D.; et al. Protein carbonylation of an amino acid residue of the Na/K-ATPase alpha1 subunit determines $\mathrm{Na} / \mathrm{K}$-ATPase signaling and sodium transport in renal proximal tubular cells. J. Am. Heart Assoc. 2016, 5, e003675. [CrossRef] [PubMed]

47. Bibert, S.; Liu, C.C.; Figtree, G.A.; Garcia, A.; Hamilton, E.J.; Marassi, F.M.; Sweadner, K.J.; Cornelius, F.; Geering, K.; Rasmussen, H.H. FXYD proteins reverse inhibition of the $\mathrm{Na}^{+}-\mathrm{K}^{+}$pump mediated by glutathionylation of its $\beta 1$ subunit. J. Biol. Chem. 2011, 286, 18562-18572. [CrossRef] [PubMed]

48. Bogdanova, A.; Petrushanko, I.Y.; Hernansanz-Agustín, P.; Martínez-Ruiz, A. “Oxygen Sensing” by Na,K-ATPase: These miraculous thiols. Front. Physiol. 2016, 7, 314. [CrossRef] [PubMed]

49. Kennedy, D.J.; Chen, Y.; Huang, W.; Viterna, J.; Liu, J.; Westfall, K.; Tian, J.; Bartlett, D.J.; Tang, W.H.W.; $\mathrm{Xie}, \mathrm{Z}$; et al. CD36 and Na/K-ATPase-alpha1 form a proinflammatory signaling loop in kidney. Hypertension 2013, 61, 216-224. [CrossRef] [PubMed]

50. Chen, Y.; Huang, W.; Yang, M.; Xin, G.; Cui, W.; Xie, Z.; Silverstein, R.L. Cardiotonic steroids stimulate macrophage inflammatory responses through a pathway involving CD36, TLR4, and Na/K-ATPase. Arterioscler. Thromb. Vasc. Biol. 2017, 37, 1462-1469. [CrossRef] [PubMed]

51. Chen, Y.; Kennedy, D.J.; Ramakrishnan, D.P.; Yang, M.; Huang, W.; Li, Z.; Xie, Z.; Chadwick, A.C.; Sahoo, D.; Silverstein, R.L. Oxidized LDL-bound CD36 recruits an $\mathrm{Na}^{+} / \mathrm{K}^{+}$-ATPase-Lyn complex in macrophages that promotes atherosclerosis. Sci. Signal. 2015, 8, ra91. [CrossRef] [PubMed]

52. Pasdois, P.; Quinlan, C.L.; Rissa, A.; Tariosse, L.; Vinassa, B.; Costa, A.D.; Pierre, S.V.; Santos, P.D.; Garlid, K.D. Ouabain protects rat hearts against ischemia-reperfusion injury via pathway involving src kinase, mitoK $_{\mathrm{ATP}}$, and ROS. Am. J. Physiol. Heart Circ. Physiol. 2007, 292, H1470-H1478. [CrossRef] [PubMed]

53. Liu, L.; Li, J.; Liu, J.; Yuan, Z.; Pierre, S.V.; Qu, W.; Zhao, X.; Xie, Z. Involvement of $\mathrm{Na}^{+} / \mathrm{K}^{+}$-ATPase in hydrogen peroxide-induced hypertrophy in cardiac myocytes. Free Radic. Biol. Med. 2006, 41, 1548-1556. [CrossRef] [PubMed]

54. Wang, Y.; Ye, Q.; Liu, C.; Xie, J.X.; Yan, Y.; Lai, F.; Duan, Q.; Li, X.; Tian, J.; Xie, Z. Involvement of Na/K-ATPase in hydrogen peroxide-induced activation of the Src/ERK pathway in LLC-PK1 cells. Free Radic. Biol. Med. 2014, 71, 415-426. [CrossRef] [PubMed]

55. Tian, J.; Cai, T.; Yuan, Z.; Wang, H.; Liu, L.; Haas, M.; Maksimova, E.; Huang, X.; Xie, Z. Binding of Src to $\mathrm{Na}^{+} / \mathrm{K}^{+}$-ATPase forms a functional signaling complex. Mol. Biol. Cell 2006, 17, 317-326. [CrossRef] [PubMed]

56. Li, Z.; Zhang, Z.; Xie, J.X.; Li, X.; Tian, J.; Cai, T.; Cui, H.; Ding, H.; Shapiro, J.I.; Xie, Z. Na/K-ATPase mimetic pNaKtide peptide inhibits the growth of human cancer cells. J. Biol. Chem. 2011, 286, 32394-32403. [CrossRef] [PubMed]

57. Liu, J.; Tian, J.; Chaudhry, M.; Maxwell, K.; Yan, Y.; Wang, X.; Shah, P.T.; Khawaja, A.A.; Martin, R.; Robinette, T.J.; et al. Attenuation of Na/K-ATPase mediated oxidant amplification with pNaKtide ameliorates experimental uremic cardiomyopathy. Sci. Rep. 2016, 6, 34592. [CrossRef] [PubMed]

58. Sodhi, K.; Maxwell, K.; Yan, Y.; Liu, J.; Chaudhry, M.A.; Getty, M.; Xie, Z.; Abraham, N.G.; Shapiro, J.I. pNaKtide inhibits $\mathrm{Na} / \mathrm{K}$-ATPase reactive oxygen species amplification and attenuates adipogenesis. Sci. Adv. 2015, 1, e1500781. [CrossRef] [PubMed] 
59. Sodhi, K.; Srikanthan, K.; Goguet-Rubio, P.; Nichols, A.; Mallick, A.; Nawab, A.; Martin, R.; Shah, P.T.; Chaudhry, M.; Sigdel, S.; et al. pNaKtide Attenuates steatohepatitis and atherosclerosis by blocking $\mathrm{Na} / \mathrm{K}-\mathrm{ATP} a \mathrm{se} / \mathrm{ROS}$ amplification in C57B16 and ApoE knockout mice fed a western diet. Sci. Rep. 2017, 7, 193. [CrossRef] [PubMed]

60. Sodhi, K.; Nichols, A.; Mallick, A.; Klug, R.L.; Liu, J.; Wang, X.; Srikanthan, K.; Goguet-Rubio, P.; Nawab, A.; Pratt, R.; et al. The Na/K-ATPase oxidant amplification loop regulates aging. Sci. Rep. 2018, 8, 9721. [CrossRef] [PubMed]

61. Cheng, X.; Song, Y.; Wang, Y. pNaKtide ameliorates renal interstitial fibrosis through inhibition of sodium-potassium adenosine triphosphatase-mediated signaling pathways in unilateral ureteral obstruction mice. Nephrol. Dial. Transplant. 2018. [CrossRef] [PubMed]

62. Liu, J.; Xie, Z.J. The sodium pump and cardiotonic steroids-induced signal transduction protein kinases and calcium-signaling microdomain in regulation of transporter trafficking. Biochim. Biophys. Acta 2010, 1802, 1237-1245. [CrossRef] [PubMed]

63. McDonough, A.A. Mechanisms of proximal tubule sodium transport regulation that link extracellular fluid volume and blood pressure. Am. J. Physiol. 2010, 298, R851-R861. [CrossRef] [PubMed]

64. McDonough, A.A.; Leong, P.K.; Yang, L.E. Mechanisms of pressure natriuresis: How blood pressure regulates renal sodium transport. Ann. N. Y. Acad. Sci. 2003, 986, 669-677. [CrossRef] [PubMed]

65. Hu, M.C.; Fan, L.; Crowder, L.A.; Karim-Jimenez, Z.; Murer, H.; Moe, O.W. Dopamine acutely stimulates $\mathrm{Na}^{+} / \mathrm{H}^{+}$exchanger (NHE3) endocytosis via clathrin-coated vesicles: Dependence on protein kinase A-mediated NHE3 phosphorylation. J. Biol. Chem. 2001, 276, 26906-26915. [CrossRef] [PubMed]

66. Chibalin, A.V.; Katz, A.I.; Berggren, P.O.; Bertorello, A.M. Receptor-mediated inhibition of renal $\mathrm{Na}(+)-\mathrm{K}(+)$-ATPase is associated with endocytosis of its $\alpha$ - and $\beta$-subunits. Am. J. Physiol. 1997, 273, C1458-C1465. [CrossRef] [PubMed]

67. Chibalin, A.V.; Ogimoto, G.; Pedemonte, C.H.; Pressley, T.A.; Katz, A.I.; Féraille, E.; Berggren, P.-O.; Bertorello, A.M. Dopamine-induced endocytosis of $\mathrm{Na}^{+}, \mathrm{K}^{+}$-ATPase is initiated by phosphorylation of Ser-18 in the rat alpha subunit and is responsible for the decreased activity in epithelial cells. J. Biol. Chem. 1999, 274, 1920-1927. [CrossRef] [PubMed]

68. Bacic, D.; Kaissling, B.; McLeroy, P.; Zou, L.; Baum, M.; Moe, O.W. Dopamine acutely decreases apical membrane $\mathrm{Na} / \mathrm{H}$ exchanger NHE3 protein in mouse renal proximal tubule. Kidney Int. 2003, 64, 2133-2141. [CrossRef] [PubMed]

69. Liu, J. Ouabain-induced endocytosis and signal transduction of the Na/K-ATPase. Front. Biosci. 2005, 10, 2056-2063. [CrossRef] [PubMed]

70. Liu, J.; Kesiry, R.; Periyasamy, S.M.; Malhotra, D.; Xie, Z.; Shapiro, J.I. Ouabain induces endocytosis of plasmalemmal Na/K-ATPase in LLC-PK1 cells by a clathrin-dependent mechanism. Kidney Int. 2004, 66, 227-241. [CrossRef] [PubMed]

71. Liu, J.; Liang, M.; Liu, L.; Malhotra, D.; Xie, Z.; Shapiro, J. IOuabain-induced endocytosis of the plasmalemmal $\mathrm{Na}$ /K-ATPase in LLC-PK1 cells requires caveolin-1. Kidney Int. 2005, 67, 1844-1854. [CrossRef] [PubMed]

72. Liu, J.; Periyasamy, S.M.; Gunning, W.; Fedorova, O.V.; Bagrov, A.Y.; Malhotra, D.; Xie, Z.; Shapiro, J.I. Effects of cardiac glycosides on sodium pump expression and function in LLC-PK1 and MDCK cells. Kidney Int. 2002, 62, 2118-2125. [CrossRef] [PubMed]

73. Liu, J.; Shapiro, J.I. Regulation of sodium pump endocytosis by cardiotonic steroids: Molecular mechanisms and physiological implications. Pathophysiology 2007, 14, 171-181. [CrossRef] [PubMed]

74. Periyasamy, S.M.; Liu, J.; Tanta, F.; Kabak, B.; Wakefield, B.; Malhotra, D.; Kennedy, D.J.; Nadoor, A.; Fedorova, O.V.; Gunning, W.; et al. Salt loading induces redistribution of the plasmalemmal Na/K-ATPase in proximal tubule cells. Kidney Int. 2005, 67, 1868-1877. [CrossRef] [PubMed]

75. Yan, Y.; Haller, S.; Shapiro, A.; Malhotra, N.; Tian, J.; Xie, Z.; Malhotra, D.; Shapiro, J.I.; Liu, J. Ouabain-stimulated trafficking regulation of the $\mathrm{Na} / \mathrm{K}$-ATPase and NHE3 in renal proximal tubule cells. Mol. Cell. Biochem. 2012, 367, 175-183. [CrossRef] [PubMed]

76. Oweis, S.; Wu, L.; Kiela, P.R.; Zhao, H.; Malhotra, D.; Ghishan, F.K.; Xie, Z.; Shapiro, J.I.; Liu, J. Cardiac glycoside downregulates NHE3 activity and expression in LLC-PK1 cells. Am. J. Physiol. Renal Physiol. 2006, 290, F997-F1008. [CrossRef] [PubMed] 
77. Cai, H.; Wu, L.; Qu, W.; Malhotra, D.; Xie, Z.; Shapiro, J.I.; Liu, J. Regulation of apical NHE3 trafficking by ouabain-induced activation of basolateral Na/K-ATPase receptor complex. Am. J. Physiol. Cell Physiol. 2008, 294, C555-C563. [CrossRef] [PubMed]

78. Liu, J.; Yan, Y.; Liu, L.; Xie, Z.; Malhotra, D.; Joe, B.; Shapiro, J.I. Impairment of Na/K-ATPase signaling in renal proximal tubule contributes to Dahl salt-sensitive hypertension. J. Biol. Chem. 2011, 286, 22806-22813. [CrossRef] [PubMed]

79. Shah, P.T.; Martin, R.; Yan, Y.; Shapiro, J.I.; Liu, J. Carbonylation modification regulates Na/K-ATPase signaling and salt sensitivity: A review and a hypothesis. Front. Physiol. 2016, 7, 256. [CrossRef] [PubMed]

80. McPherson, P.S.; Kay, B.K.; Hussain, N.K. Signaling on the endocytic pathway. Traffic 2001, 2, $375-384$. [CrossRef] [PubMed]

81. Cavalli, V.; Corti, M.; Gruenberg, J. Endocytosis and signaling cascades: A close encounter. FEBS Lett. 2001, 498, 190-196. [CrossRef]

82. Di Guglielmo, G.M.; Baass, P.C.; Ou, W.J.; Posner, B.I.; Bergeron, J.J. Compartmentalization of SHC, GRB2 and mSOS, and hyperphosphorylation of Raf-1 by EGF but not insulin in liver parenchyma. EMBO J. 1994, 13, 4269-4277. [PubMed]

83. Roy, S.; Wyse, B.; Hancock, J.F. H-Ras signaling and K-Ras signaling are differentially dependent on endocytosis. Mol. Cell. Biol. 2002, 22, 5128-5140. [CrossRef] [PubMed]

84. Wilde, A.; Beattie, E.C.; Lem, L.; Riethof, D.A.; Liu, S.H.; Mobley, W.C.; Soriano, P.; Brodsky, F.M. EGF receptor signaling stimulates SRC kinase phosphorylation of clathrin, influencing clathrin redistribution and EGF uptake. Cell 1999, 96, 677-687. [CrossRef]

85. Ware, M.F.; Tice, D.A.; Parsons, S.J.; Lauffenburger, D.A. Overexpression of cellular Src in fibroblasts enhances endocytic internalization of epidermal growth factor receptor. J. Biol. Chem. 1997, 272, 30185-30190. [CrossRef] [PubMed]

86. Wiley, H.S.; Burke, P.M. Regulation of receptor tyrosine kinase signaling by endocytic trafficking. Traffic 2001, 2, 12-18. [CrossRef] [PubMed]

87. Kuwada, S.K.; Lund, K.A.; Li, X.F.; Cliften, P.; Amsler, K.; Opresko, L.K.; Wiley, H.S. Differential signaling and regulation of apical vs. basolateral EGFR in polarized epithelial cells. Am. J. Physiol. 1998, 275, C1419-C1428. [CrossRef] [PubMed]

88. Liu, J.; Lilly, M.N.; Shapiro, J.I. Targeting Na/K-ATPase signaling: A new approach to control oxidative stress. Curr. Pharm. Des. 2018, 24, 359-364. [CrossRef] [PubMed]

89. Li, Z.; Xie, Z. The Na/K-ATPase/Src complex and cardiotonic steroid-activated protein kinase cascades. Pflugers Arch. 2009, 457, 635-644. [CrossRef] [PubMed]

90. Pierre, S.V.; Xie, Z. The Na,K-ATPase receptor complex: Its organization and membership. Cell Biochem. Biophys. 2006, 46, 303-316. [CrossRef]

91. Bagrov, A.Y.; Shapiro, J.I.; Fedorova, O.V. Endogenous cardiotonic steroids: Physiology, pharmacology, and novel therapeutic targets. Pharmacol. Rev. 2009, 61, 9-38. [CrossRef] [PubMed]

92. Weigand, K.M.; Swarts, H.G.; Fedosova, N.U.; Russel, F.G.; Koenderink, J.B. Na,K-ATPase activity modulates Src activation: A role for ATP/ADP ratio. Biochim. Biophys. Acta 2012, 1818, 1269-1273. [CrossRef] [PubMed]

93. Gable, M.E.; Abdallah, S.L.; Najjar, S.M.; Liu, L.; Askari, A. Digitalis-induced cell signaling by the sodium pump: On the relation of Src to $\mathrm{Na}^{+} / \mathrm{K}^{+}$-ATPase. Biochem. Biophys. Res. Commun. 2014, 446, 1151-1154. [CrossRef] [PubMed]

94. Yosef, E.; Katz, A.; Peleg, Y.; Mehlman, T.; Karlish, S.J. Do Src kinase and Caveolin interact directly with Na,K-ATPase? J. Biol. Chem. 2016, 291, 11736-11750. [CrossRef] [PubMed]

(C) 2018 by the authors. Licensee MDPI, Basel, Switzerland. This article is an open access article distributed under the terms and conditions of the Creative Commons Attribution (CC BY) license (http://creativecommons.org/licenses/by/4.0/). 